Virginia Commonwealth University vCU Scholars Compass

\title{
Adult Learning Theory and Reference Services: Consonances and Potentials
}

Jimmy Ghaphery

Virginia Commonwealth University, jghapher@vcu.edu

Follow this and additional works at: http://scholarscompass.vcu.edu/libraries_pubs

Part of the Adult and Continuing Education and Teaching Commons, and the Library and Information Science Commons

copyright Taylor \& Francis

\section{Downloaded from}

http://scholarscompass.vcu.edu/libraries_pubs/10

This Article is brought to you for free and open access by the VCU Libraries at VCU Scholars Compass. It has been accepted for inclusion in VCU Libraries Faculty and Staff Publications by an authorized administrator of VCU Scholars Compass. For more information, please contact libcompass@vcu.edu. 


\title{
Adult Learning Theory and Reference Services: Consonances and Potentials
}

\section{James Ghaphery}

\author{
$\underline{\text { Abstract }}$ \\ development. \\ $\underline{\text { Keywords }}$ \\ Adult Education \\ Reference Services \\ Discussion Groups \\ Continuing Education
}

There is long history of exchange between librarians and adult educators. This history not only points to previous successes but also highlights a tension of defining an appropriate focus within libraries for the provision of adult education. The similarities between contemporary adult education thought and reference services can provide some interesting possibilities in looking toward the future of reference in a digital age, both in terms of service and professional

Librarian for Instructional Technology, University Library Services, Office for Information Technology, Virginia Commonwealth University

B.A. College of William and Mary, M.T. Virginia Commonwealth University, M.Ed. Virginia Commonwealth University

James Ghaphery

Instruction and Outreach

901 Park Ave

Box 842033

University Library Services

Richmond, Va 23284-2033

Jsghaphe@vcu.edu 
Adult Learning Theory and Reference Services: Consonances and Potentials

James Ghaphery

James Ghaphery is Librarian for Instructional Technology, James Branch Cabell Library, 901 Park Ave, Office for Information Technology, Virginia Commonwealth University, Richmond, Virginia, 23284-2033

E-mail: Jsghaphe@vcu.edu 


\section{$\underline{\text { A Selected Review }}$}

The history of adult education and libraries in America are closely intertwined. In his seminal article, "The Profession", in the first issue of the American Library Journal, Melvil Dewey concluded by tying the future of the profession to the transformation of the librarian from "a mouser in musty books" to an individual who is "in the highest sense a teacher" (1876). More than a century later, American Library Association President Barbara Ford drew on the vocabulary of adult education in calling for "lifelong learning" opportunities for librarians, staff, and the general public (1998). Indeed much of the American Library Association's efforts are connected to adult education. This is clearly reflected in the charges of various divisions and roundtables such as the Public Library Association, Reference and User Services Association, Continuing Library Education Network Exchange Round Table, and the Library Instruction Round Table.

Likewise, the field of adult education has often drawn upon library resources and librarians. Early adult education efforts in colonial America, such as Benjamin Franklin's Junto, centered on access to books within collective, public and personal libraries (Stubblefield and Keane, 1994). Further, Malcolm Knowles, in his history of adult education, not only traced the relationship between adult education and libraries, but also cited successful outreach efforts from the library community to other educational professionals (1976).

Several works from the library literature have thoroughly detailed the history of adult education in the context of the library. Among these, C. Walter Stones' article "Adult Education and the Public Library" (1953), Robert Lee's Continuing Education for Adults through the American Public Library, 1833-1964 (1966), Lynn Birge's Serving Adult Learners: A Public Library Tradition (1981), and Connie Van Fleet's “Lifelong Learning Theory and the Provision 
of Adult Services" (1990), are especially noteworthy. Despite the fact that these works were written over a period of four decades, a number of interrelated issues emerge. Foremost, the American library enjoys a long history of educational outreach and support to a wide variety of adults. Given this record, there remains the difficulty of defining what exactly constitutes adult education in libraries. This difficulty surfaces in the long running debate over the level of service and support that should be offered for library adult education.

\section{Defining a Level of Service to Adults}

It is indeed hard to mention any library service that does not in some way contribute to the potential for adult learning. From a well cataloged book to the reference interview, the efforts of libraries create structures and avenues for learning. The level of service for adult education, on the other hand, brings the difficulties in definition to the fore. The debate has revolved around how much initiative librarians, apart from their traditional roles, should take in designing or leading adult education programs. Dilemmas of decreasing budgets and increasing demands make these choices even more contested.

Amidst historical swings of emphasis among such areas as reader's advisory services, community outreach programs, and library instruction, the library has remained central to the continuing education of adults. The educational contexts are as diverse as our library systems including university libraries in conjunction with an organized curriculum of study, public libraries for vocational or recreational research, and special libraries such as a state archives for genealogical research. Especially interesting is the degree to which the library literature and adult education theory have charted parallel courses. Van Fleet effectively argues that the 1852 Report to the Boston Public Library contains the philosophical kernel of the 1970's educational concept of lifelong learning. She states, "Obviously then, lifelong learning theory and the underlying 
foundations of the public library have much in common: both recognize the importance of continuing universal education for vocational and personal development" (p. 170).

\section{Lindeman and Knowles}

Modern adult education theory has developed among many avenues, theorists, and practictioners. Among these, the work of both Eduard Lindeman and Malcolm Knowles is fundamental. Lindeman's The Meaning of Adult Education, spoke passionately about the unmet needs of adults learners (1920). Always central to his conception of adult education was the importance of the individual's experience. Lindeman argued that the adult's experience was too often marginalized in the educational process. He stated, "The resource of highest value in adult education is the learner's experience... Too much of learning consists of vicarious substitution of some one else's experience and knowledge" (p. 9). Building on the ideas of Lindeman, Malcolm Knowles constructed the model of andragogy:

For more than four decades I have been trying to formulate a theory of adult learning that takes into account what we know from experience and research about the unique characteristics of adult learners. Originally (in Informal Adult Education, 1950), I organized my ideas around the notion that adults learn best in informal, comfortable, flexible, nonthreatening settings. Then in the mid-1960's I was exposed to the term andragogy .... And it seemed to me to be a more adequate organizing concept...(1990, p. 54).

Like Lindeman, Knowles never drifted far from the individual's experience. Other essential components of andragogy include the importance of the overall context of learning for adults. This context must take into account the relationship between what is to be learned and the learner's life as well as the "why" behind any learning endeavor. For example, think of the Library of Congress classification system. Knowles would maintain that if you wanted to teach this system to adults, you must do so in the overall context of their quest for a specific book as opposed to setting up a class every Thursday night on cataloging practices. 


\section{The Reference Interview and Adult Learning Theory}

As the preceding example demonstrates there are many specific similarities between adult learning theory and the philosophy behind reference services. We do not regularly offer classes on discrete facets of librarianship, but teach at the reference desk from the patron's need. The reference interview is especially illustrative of Knowles' life centered model of education. Where adult learning theory focuses on the needs of each adult as an individual, the reference transaction by its nature is already individualized. More important than the presence of a self motivated learner (or patron with a research question), is the transaction between the instructor and learner. The heart of the reference interview speaks to the importance of communication between librarian and patron. This communication, through the use of open ended questions serves as a goal clarification for both the librarian and the learner. In terms of adult learning theory, this interaction would be characterized as "facilitation" or helping the adult learner map or clarify his own course of study. This facilitation process is guided by the listening and questioning skills of the facilitator.

\section{Collaborative Learning}

Another hallmark of adult learning theory is the concept of group interaction (Brookfield, 1986). Collaborative learning acknowledges both the social nature of learning and the richness of personal experience that each person in a group can bring to an educational setting. In the traditional reference setting it is hard to envision directing a patron toward another researcher and suggesting that they compare notes or chat about their research. While librarians, deservedly, serve as the primary experts for research consultation and each patron has the right to consider the reference interview as confidential, it is important to consider the potential of collaborative learning and how it might be employed within and outside the walls of the library. 
I am often intrigued by the learning which occurs when our students give each other advice in the reference area. At their best, these interactions often result in mutual learning, where both students come to understand a wider breadth of the research possibilities at the library. At their worst, without professional guidance, misinformation can easily be distributed. This dilemma is a good illustration of the fine line an adult education facilitator must walk between too much or too little intervention in a collaborative learning environment. I should also note that our student population at Virginia Commonwealth University is very diverse and like many colleges and universities is made up of a large percentage of returning adult students. In a recent ACRL 1997 conference paper, Dolores Fidishun has recognized the intersection of this changing demographic and adult learning practices and has elaborated some interesting recommendations and challenges to the library community.

While not advocating the abolition of the reference desk as an efficient vehicle for delivering quality research advice, I believe that we can look toward supplemental services that may capitalize on collaborative learning techniques. That is, we should be able to provide a space both for group interaction and professional input. The emerging environment of digital reference offers us new opportunities to link our users up with one another. Listserv technology has been employed by a number of college and university libraries as a mechanism for students to post questions and for librarians to engage in extended conversations about research. Likewise, electronic reference is reaching a large remote population through sites such as the Internet Public Library. Our net of referral possibilities has also been greatly expanded when we consider the variety of listservs or synchronous electronic conferencing where discussions of highly specific issues are taking place beyond traditional geographical boundaries. 
Collaborative learning theory has also impacted instruction throughout the educational system as more and more students and adults are called on to wrestle with problems in small groups or teams. In touring two newly constructed libraries (Virginia Theological University and Eastern Michigan University), I was struck by the architectural acknowledgement of this shift as numerous group study rooms were included, complete with wiring and white boards. It will be interesting to see if such rooms welcome librarians as well as students. That is, if the group has a research question, must they trudge over to the reference desk or can a group consultation take place in the study room or through the wiring? In terms of venturing into the areas of collaborative learning, such pre-formed task oriented groups seem like a logical starting point and could offer a compelling field of study.

It is interesting to consider epistemological questions and the librarian's role in these types of conversations. If one believes that knowledge can be created through interaction, then much is to be gained from opening up the reference interview to a larger group. That is, while the librarian has valuable research advice as a subject matter and research specialist, other participants in the group may pose valid questions and advice as well. The fundamental question does return to "role". If listervs and groups are valid research tools, then should the librarian merely refer a patron to an appropriate list or should the librarian be an active participant within the list? As an institution committed to education, does the library have a role in hosting virtual discussions on pressing local or global issues? The reference librarian is certainly well poised in terms of training and experience to become a rich resource in such an arena.

\section{Critical Reflection}

Contemporary adult education theorists have emphasized the overall quality of the educational experience. Stephen Brookfield has elaborated a distinction between "training" and 
“education” (1986). Training, for Brookfield, involves the teaching of discrete skills while education deals with deeper issues of personal reflection and the development of a critical awareness. In a similar spirit, Jack Mezirow sees the educational endeavor as a means to question, challenge and transform our previously held beliefs and values (1990).

The resources for this type of education are certainly present in a library setting where competing voices sing out next to each other on the shelves or from amongst growing digital collections. Do we step into these larger goals of adult education or simply maintain a setting where critical reflection may or may not occur? These contemporary rubrics go to the heart of the debate over the level and type of library adult education that we offer.

The emerging issues of information literacy dovetail with the ideas of critical reflection. An information literate person is "able to recognize when information is needed and have the ability to locate, evaluate, and use effectively the needed information" (American Library Association Presidential Committee on Information Literacy, 1989). These skills are intertwined with the ideas of critical reflection and adult education, especially when we move beyond simple retrieval of specific information to the more complex information tasks of analyzing competing theories and reconciling them with one's own beliefs. It is this personal struggle for meaning that educators such as Brookfield and Mezirow look to as the heart of the educational enterprise. Such a struggle offers the opportunity for significant learning and reflection. In terms of teaching information literacy skills, we may do well to search for these teachable moments when information retrieval interacts with personal value clarification and meaning making.

\section{Continuing Professional Education}

In the area of continuing professional education, the concept of critical reflection gives us a powerful avenue for renewal and engagement. Donald Schon has offered a challenging portrait 
for all professions (1986). He argues that the telltale sign of a professional is not to be found in the certification process or in a scientific body of knowledge. Instead, he looks to the zone of actual practice where such preparation can only take one but so far. In practice, the professional must make difficult decisions that do not fit neatly into pre-defined categories. While Schon writes about professions in general, the following is arrestingly descriptive of the reference process: "She [the professional] responds to the unexpected or anomalous by restructuring some of her strategies of action, theories of phenomena, or ways of framing the problem; and she invents on-the-spot experiments to put her new understandings to the test" (p. 35). Schon sees this type of action as more artistic than scientific and calls for such ongoing reflection to resonate throughout our understanding of and thoughts about the profession.

We, as professionals, must take advantage of the accrued knowledge from each reference interview and interaction. The potential of such an artistic professional is greatly enhanced by reflection on past practices. Why did I recommend that particular source? What questions did I ask the patron? This ability to reflect both during and after the reference encounter is especially critical as we chart new areas of reference. Such reflection can serve as a basis for creatively moving into new realms of digital reference.

\section{Conclusion}

Looking to and reflecting upon other disciplines can challenge our own preconceptions and values. In the case of adult education, I have merely scratched the surface of the potential alliances. The historical precedent is strong for collaboration across these disciplines. More importantly, the challenges of our current age reach beyond singular solutions and paradigms. The time is ripe for greater exchange between librarians and adult educators. The process would 
serve to enrich both parties and more importantly present dynamic and exciting educational opportunities for library patrons.

\section{$\underline{\text { References }}$}

American Library Association Presidential Committee on Information Literacy (1989), American Library Association Presidential Committee on Information Literacy: Final Report. Online: http://www.ala.org/acrl/nili/ilit1st.html.

Brookfield, Stephen (1986), Understanding and Facilitating Adult Learning, San Francisco: Jossey-Bass.

Dewey, Melvil (1876), “The Profession.” American Library Journal 1 (1), 5-6.

Fidishun, Dolores (1997), "Can We Still Do Business as Usual? Adult Students and the New Paradigm of Library Service.” ACRL 1997 National Conference Papers. Online: http://www.ala.org/acrl/paperhtm/c25.html.

Ford, Barbara (1998), "Lifelong Learning: Global Reach and Local Touch”. American Libraries 29 (3), 33.

Internet Public Library. Online: http://ipl.si.umich.edu/.

Knowles, Malcolm (1950), Informal Adult Education, New York: Association Press.

Knowles, Malcolm (1977), A History of the Adult Education Movement in the United States, Huntington, New York: Robert E. Krieger Publishing Company.

Knowles, Malcolm (1990), The Adult Learner: A Neglected Species, $4^{\text {th }}$ ed. Houston: Gulf Publishing Company.

Lee, Robert (1966), Continuing Education for Adults through the American Public Library 18331964, Chicago: American Library Association.

Lindeman, Eduard (1926), The Meaning of Adult Education, New York: New Republic.

Mezirow, Jack (1990), Fostering Critical Reflection in Adulthood, San Francisco: Jossey-Bass.

Stone, C. Walter (1953), “Adult Education and the Public Library" Library Trends 1 (April), 437-453.

Stubblefield, Harold and Patrick Keane (1994), Adult Education in the American Experience, San Francisco: Jossey-Bass. 
Van Fleet, Connie (1990), "Lifelong Learning Theory and the Provision of Adult Services," In Adult Services: An Enduring Focus for Public Libraries, edited by Kathleen Heim and Danny Wallace. Chicago: American Library Association, 166-211. 